\title{
AIDA: a methodology independent support tool for educational software authoring
}

\author{
ANTÓNIO JOSÉ MENDES \\ Departamento de Engenharia Informática da Universidade de Coimbra, Pólo \\ II, Pinhal de Marrocos, 3030 Coimbra, Portugal. \\ E-mail: toze@eden.dei.uc.pt
}

\section{TERESA MENDES}

Departamento de Engenharia Informática da Universidade de Coimbra, Pólo II, Pinhal de Marrocos, 3030 Coimbra, Portugal.

E-mail: tmendes@eden.dei.uc.pt

Many authoring tools have been proposed in an attempt to find more effective ways to face the challenge of developing educational software. However, most of them are reported to be restrictive, since they are strongly connected to a specific educational software development methodology. The AIDA (Ambiente Integrado para o Desenvolvimento de Aplicações educacionais) authoring environment was developed at the University of Coimbra having as its main objectives the support of most of the activities involved in authoring and making educational software development easier. The AIDA system is based on a design module, i.e. a prototyping tool allowing the creation of Windows-based software, including multimedia features. The system assists evaluation activities and it caters also for support on translation and cultural adaptation, as well as on the reutilization of educational materials. The use of the AIDA environment is illustrated by three small examples using different development methodologies.

KEYWORDS: software; authoring systems.

\section{INTRODUCTION}

Computer technology presents pedagogical potentialities that, if properly used, can be a valuable instrument in teaching and learning. To take advantage fully of those potentialities it is essential to use good quality educational software. Generic packages, like word processors and databases, can be useful in several 